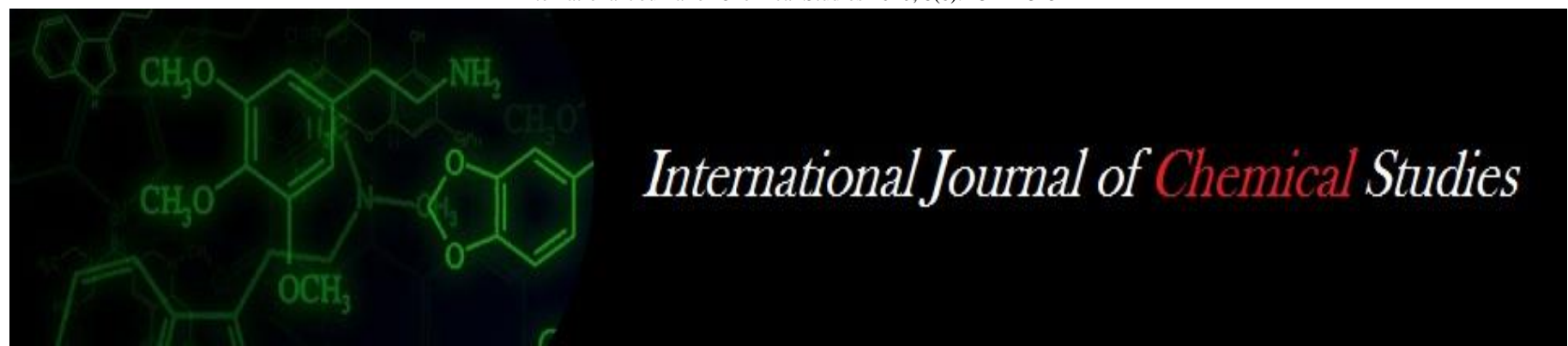

P-ISSN: 2349-8528

E-ISSN: 2321-4902

www.chemijournal.com

IJCS 2020; 8(6): 1311-1315

(C) 2020 IJCS

Received: 07-09-2020

Accepted: 10-10-2020

Dommalapati Sudhakara Rao Department of Chemistry and Biochemistry, Chaudhary

Charan Singh Haryana

Agricultural University, Hisar,

Haryana, India

\title{
Midathala Raghavendra
}

Department of Chemistry and

Biochemistry, Chaudhary

Charan Singh Haryana

Agricultural University, Hisar,

Haryana, India

\section{Parveen Gill}

Department of Zoology, Chaudhary Charan Singh

Haryana Agricultural University, Hisar, Haryana,

India

\section{Shashi Madan}

Department of Chemistry and

Biochemistry, Chaudhary

Charan Singh Haryana

Agricultural University, Hisar,

Haryana, India

Renu Munjal

Department of Genetics and

Plant Breeding, Chaudhary

Charan Singh Haryana

Agricultural University, Hisar,

Haryana, India

Corresponding Author:

Dommalapati Sudhakara Rao Department of Chemistry and Biochemistry, Chaudhary

Charan Singh Haryana

Agricultural University, Hisar,

Haryana, India

\section{Effect of oxidative stress on chlorophyll fluorescence, canopy temperature and total leaf protein content in Wheat (Triticum aestivum $\mathrm{L}$.) under drought during post anthesis period}

\author{
Dommalapati Sudhakara Rao, Midathala Raghavendra, Parveen Gill, \\ Shashi Madan and Renu Munjal
}

DOI: https://doi.org/10.22271/chemi.2020.v8.i6s.10941

\begin{abstract}
Drought stress induced physiological changes such as chlorophyll fluorescence, canopy temperature and total leaf protein were studied in the present investigation in two wheat varieties viz. WH 1105 and WH 1025. Chlorophyll fluorescence is excellent tool to study stress induced changes in PSII. The $F_{v} / F_{m}$ value denotes the injury to PS II due to influence of stress factors. Chlorophyll fluorescence decreased under drought stress in leaves of both varieties from $7^{\text {th }}$ to $28^{\text {th }}$ DAA. Canopy temperature indicates crop water status. Canopy temperature of 31.98 o $\mathrm{C}$ was recorded at $28^{\text {th }} \mathrm{DAA}$ in $\mathrm{WH} 1105$ and the value is lower in WH 1025. Total soluble protein content was decreased under drought stress in leaf samples. Total soluble protein levels in leaves do not clearly indicate senescence symptoms driven by severe drought at grain filling period.
\end{abstract}

Keywords: Wheat (Triticum aestivum L.), oxidative stress, anthesis, chlorophyll fluorescence, canopy temperature and total leaf protein

\section{Introduction}

Abiotic stress is one of the main reasons for reduction of yield potentials in wheat crop. Irregular and uneven distribution of precipitation patterns results water deficiet conditions across nations. Plants show range of physiological responses to shortage of water. Acclimatization of plants to water deficiet is the result of different events which led to adaptive changes in plant growth and physio-biochemical processes such as changes in plant structure, growth rate, tissue osmotic potential and antioxidant defense. About 37 per cent of the world wheat is grown in semi-arid areas where moisture is the most serious production constraint (Moussav N. et al., 1997) ${ }^{[13]}$. Understanding of physiological mechanism that enable plants to adapt to water deficit and maintain growth production during stress period could help in screening and selection of tolerant genotypes. Chlorophyll fluorescence and canopy temperatures are among the main physiological criteria that influence plant water relations and have been used for assessing drought tolerance (Kocheva et al., 2009; Ezatollah et al., 2012; Usha \& Bhumika 2012) ${ }^{[11,22]}$.The first response of virtually all plants to acute water shortage is the closure of stomata to prevent transpirational water loss, which may result in response to decrease in leaf turgour and water potential besides increasing the canopy temperature (Sudhakara R.D., et al, 2020) ${ }^{[21]}$. Stomatal closure may lead to increased susceptibility to photo damage. Chlorophyll fluorescence can give insights into ability of a plant to tolerate environmental stresses and to the extent to which those stresses damaged the photosynthetic apparatus (Lobna et al., 2009) ${ }^{[9]}$. Overexpressed glycine betaine increases the tolerance of the plants to all stresses in terms of maintain photosynthesis rates (Wang et al., $2010)^{[23]}$. The synthesis of protein in leaves was adversely affected by enhancement of canopy temperature. Tolerance to abiotic stresses is very complex due to intricate interactions between stress factors and various physiological and biochemical phenomenon affecting plant growth and development. Drought stress tolerance is seen in almost all species and even within species with various adaptive mechanisms. One of the ways to compensate the losses due to 
water deficit in yield partially is introduction of genotypes having high range of adaptability, more osmoregulation efficacy and better photosynthetic efficiency. In the present investigation two wheat varieties were selected for studying physiological responses of plants to drought stress during post anthesis period.

\section{Materials and Methods}

Seeds of two varieties of wheat viz. WH 1105 (Drought sensitive) and WH 1025 (Drought tolerant) were obtained from Wheat and Barley Section, Department of Genetics and Plant Breeding, College of Agriculture, CCSHAU, Hisar. Seeds were sown in micro plots in the university farm. Drought stress was created by giving pre sown irrigation only for the micro plots designated for this purpose. Normal agronomical recommended irrigations were given for other micro plots. Leaf samples were collected at four stages starting from $7^{\text {th }}$ day after anthesis $(7,14,21$ and 28 days). Plants samples were brought to the laboratory by keeping them in liquid nitrogen after procurement from the field. Leaf extracts were prepared in suitable extraction medium and were used for quantitative estimation of total leaf protein. Chlorophyll fluorescence and canopy temperatures were measured in leaves of standing crop in the field itself days after anthesis.

\section{Chlorophyll fluorescence}

The chlorophyll fluorescence was measured by following the method of Lobna et al. (2009) ${ }^{[8]}$, where measurements of $\mathrm{F}_{0}$, $F_{m}$ and $F_{v} / F_{m}$ were taken about $4 \mathrm{~cm}$ from the base of abaxial surface of flag leaf using a portable handy analyser (Hansatech, UK) in right sown environments at post anthesis stage. Five readings were taken from three randomly selected plants. It works on the principle of continuous excitation fluorescence. The fully expanded leaves were first acclimated to the dark for $2 \mathrm{~min}$. by fixing clips. The dark adapted samples were continuously irradiated for $1 \mathrm{sec}$, provided by an array of 3 light emitting diodes in sensor. The florescence signals were detected as $F_{0}, F_{m}$ and $F_{v} / F_{m}$. The data was analysed, which provides parameters indicating the efficiency of photosystem II. Data was recorded between 10:00 A. M. to 12:00 P. M.

\section{Canopy temperature}

Canopy temperature (CT) measurements were made using hand held infrared thermometer (IRT), model AG-42, Tele temp crop Fullerton. Five measurements were taken per plot at approximately $0.5 \mathrm{~m}$ from the edge of the plot and approximately $0.5 \mathrm{~m}$ above the canopy with an approximately $30-60^{\circ}$ from the horizontal. The canopy temperature (CT) and ambient temperature (AT) were measured between 12:00 to 14:00 hours on cloudless, bright days (Hojjat et al. 2012) ${ }^{[6]}$.

\section{Total protein content Extraction}

Total protein content was estimated by the method of Lowry et al. (1951) ${ }^{[9]}$, where sample material of $1 \mathrm{~g}$ was homogenised with $5 \mathrm{ml}$ of $0.1 \mathrm{M}$ phosphate buffer $(\mathrm{pH} 7.4)$ in mortar and pestle, centrifuged content at $8000 \mathrm{rpm}$ for $20 \mathrm{~min}$. collected the supernatant, repeated the procedure for four times, combined the supernatants and made the volume to 50 $\mathrm{ml}$ with $0.1 \mathrm{M}$ phosphate buffer ( $\mathrm{pH} \mathrm{7.4)}$.

\section{Procedure}

To $1 \mathrm{ml}$ of the supernatant, $1 \mathrm{ml}$ of $20 \%$ TCA was added, kept it for half an hour, centrifuged at $8000 \mathrm{rpm}$ for $20 \mathrm{~min}$. washed the pellet with acetone twice, centrifuged it again, and discarded supernatant. The pellet was dissolved in $5 \mathrm{ml}$ of 0.1 $\mathrm{N} \mathrm{NaOH}$ and content was mixed thoroughly till pellet get dissolved. Took suitable aliquot $(1 \mathrm{ml})$ of above solution, added $5 \mathrm{ml}$ of freshly prepared alkaline copper reagent, mixed properly, added $0.5 \mathrm{ml}$ of Folin - Ciocalteau reagent after 10 min. mixed the contents instantaneously, allowed to develop colour and absorbance was read at $660 \mathrm{~nm}$. The amount of protein in sample was determined from the standard curve of BSA $(10-100 \mu \mathrm{g})$.

\section{Results \\ Chlorophyll fluorescence}

Table 1 demonstrates the chlorophyll fluorescence $\left(F_{v} / F_{m}\right)$ in flag leaf of two wheat varieties under irrigated and drought stress conditions. Drought stress led to decline in chlorophyll fluorescence in wheat flag leaves of both varieties. The chlorophyll fluorescence ranged from 0.618 to 0.769 and 0.563 to 0.682 under irrigated and drought conditions respectively in WH 1025. Similarly, the chlorophyll fluorescence varied from 0.618 to 0.731 and 0.568 to 0.616 under irrigated and drought conditions respectively in $\mathrm{WH}$ 1105. The per cent reduction data of chlorophyll fluorescence revealed that the highest reduction (8.09 to 15.73$)$ in $\mathrm{WH}$ 1105 and lowest in WH 1025 (8.90 to11.31) from $7^{\text {th }}$ to $28^{\text {th }}$ days after anthesis. The reduction was eminent in WH 1105 trailed by WH 1025.

Table 1: Effect of drought stress on chlorophyll fluorescence $\left(\mathrm{F}_{\mathrm{v}} / \mathrm{F}_{\mathrm{m}}\right)$ in flag leaf of wheat during grain development

\begin{tabular}{|c|c|c|c|c|c|c|c|}
\hline \multirow{2}{*}{ S. No. } & \multirow{2}{*}{ DAA } & \multicolumn{3}{|c|}{ WH 1105 } & \multicolumn{2}{c|}{ WH 1025 } \\
\cline { 3 - 8 } & & Irrigated & Drought & \% Reduction & Irrigated & Drought & 0.563 \\
\hline 1 & 7 & 0.618 & 0.568 & 8.09 & 0.618 & 0.671 \\
\hline 2 & 14 & 0.700 & 0.631 & 9.81 & 0.731 & 0.90 \\
\hline 3 & 21 & 0.721 & 0.633 & 12.21 & 0.749 & 0.16 \\
\hline 4 & 28 & 0.731 & 0.616 & 15.73 & 0.769 & 0.682 \\
\hline \multicolumn{2}{|c|}{ CD at 5\% } & \multicolumn{2}{|c|}{ E NS, DAA = NS, E X DAA = NS } & \multicolumn{2}{c|}{ E = 0.021, DAA = 0.032, E X DAA = 0.053 } \\
\hline
\end{tabular}

\section{Canopy temperature}

The results presented in Table 2 exemplify that drought stress led to enhancement in canopy temperature of both varieties at different days after anthesis. Among the two varieties, higher canopy temperature was noted in WH 1105 under drought condition. The canopy temperature recorded in WH 1105 was 25.26, 26.45, 27.66 and $30.70{ }^{\circ} \mathrm{C}$ under irrigated condition and $27.20,27.90,28.90$ and $31.98^{\circ} \mathrm{C}$ under drought condition at $7^{\text {th }}, 14^{\text {th }}, 21^{\text {st }}$ and $28^{\text {th }}$ days after anthesis respectively. In WH 1025, the canopy temperature was $25.08,25.98,26.48$ and $30.36{ }^{\circ} \mathrm{C}$ under irrigated condition while under drought stress condition it was $26.32,26.64,27.32$ and $31.21^{\circ} \mathrm{C}$ at $7^{\text {th }}$, $14^{\text {th }}, 21^{\text {st }}$, and $28^{\text {th }}$ days after anthesis respectively. The maximum canopy temperature was $31.98^{\circ} \mathrm{C}$ at $28^{\text {th }}$ day after anthesis in WH 1105 under drought condition and minimum 
was $25.08{ }^{\circ} \mathrm{C}$ in $\mathrm{WH} 1025$ at $7^{\text {th }}$ day after anthesis under irrigated condition. The per cent increase varied from 7.68 to 4.17 in WH 1105 and it decreased gradually from $7^{\text {th }}$ to $28^{\text {th }}$ days after anthesis. In WH 1025, the per cent increase varied from 4.94 to 2.80 from $7^{\text {th }}$ to $28^{\text {th }}$ days after anthesis. Initially the per cent increase of canopy temperature in WH 1025 decreased from $7^{\text {th }}$ to $14^{\text {th }}$ DAA (4.94 to 2.54 ), later it was slightly increased from $14^{\text {th }}$ to $21^{\text {st }}$ DAA (2.54 to 3.17 ), finally it decreased from $21^{\text {st }}$ to $28^{\text {th }}$ DAA (3.17 to 2.80). WH 1025 showed better performance for canopy temperature in wheat leaves under irrigated and drought conditions.

Table 2: Effect of drought stress on canopy temperature $\left({ }^{\circ} \mathrm{C}\right)$ in flag leaf of wheat during grain development

\begin{tabular}{|c|c|c|c|c|c|c|c|}
\hline \multirow{2}{*}{ S. No. } & \multirow{2}{*}{ DAA } & \multicolumn{3}{|c|}{ WH 1105 } & \multicolumn{2}{c|}{ WH 1025 } \\
\cline { 3 - 8 } & & Irrigated & Drought & \% Increase & Irrigated & Drought & \% Increase \\
\hline 1 & 7 & 25.26 & 27.20 & 7.68 & 25.08 & 26.32 & 4.94 \\
\hline 2 & 14 & 26.45 & 27.90 & 5.48 & 25.98 & 26.64 & 2.54 \\
\hline 3 & 21 & 27.66 & 28.90 & 4.48 & 26.48 & 27.32 & 3.17 \\
\hline 4 & 28 & 30.70 & 31.98 & 4.17 & 30.36 & 31.21 & 2.80 \\
\hline \multicolumn{2}{|r}{ CD at 5\% } \\
\hline
\end{tabular}

\section{Total soluble protein content}

Table 3 demonstrates the total soluble protein content in flag leaf of both wheat varieties under irrigated and drought stress conditions. Drought stress led to decline in total protein content at different stages of grain development. WH 1105 showed more per cent reduction (26.60 to 12.34) and $\mathrm{WH}$ 1025 less per cent reduction (20.18 to 11.74 ) from $7^{\text {th }}$ to $28^{\text {th }}$ days after anthesis under drought stress condition.
The leaf soluble protein content decreased from 32.83 to $21.55 \mathrm{mg} \mathrm{g}^{-1}$ f. wt. and 24.09 to $18.89 \mathrm{mg} \mathrm{g}^{-1}$ f. wt. in $\mathrm{WH}$ 1105 under irrigated and drought conditions respectively, while in WH 1025 it decreased from 41.14 to 29.30 under irrigated condition and 32.84 to 25.86 under drought condition. The per cent reduction under drought varied from 26.60 to 12.34 and 20.18 to 11.74 from $7^{\text {th }}$ to $28^{\text {th }}$ days after anthesis in WH 1105 and WH 1025 respectively. The per cent reduction was higher in WH 1105 than WH 1025.

Table 3: Effect of drought stress on leaf soluble protein $\left(\mathrm{mg} \mathrm{g}^{-1} \mathrm{f}\right.$. wt.) in flag leaf of wheat during grain development

\begin{tabular}{|c|c|c|c|c|c|c|c|}
\hline \multirow{2}{*}{ S. No. } & \multirow{2}{*}{ DAA } & \multicolumn{3}{|c|}{ WH 1105 } & \multicolumn{2}{c|}{ WH 1025 } \\
\cline { 3 - 8 } & & Irrigated & Drought & \% Reduction & Irrigated & Drought & \% Reduction \\
\hline 1 & 7 & 32.82 & 24.09 & 26.60 & 41.14 & 32.84 & 20.18 \\
\hline 2 & 14 & 25.44 & 20.67 & 18.75 & 35.28 & 29.68 & 15.87 \\
\hline 3 & 21 & 24.86 & 20.44 & 17.78 & 32.20 & 27.26 & 15.34 \\
\hline 4 & 28 & 21.55 & 18.89 & 12.34 & 29.30 & 25.86 & 11.74 \\
\hline \multicolumn{2}{|r|}{ CD at 5\% $=0.46, \mathrm{DAA}=0.65, \mathrm{E} X \mathrm{DAA}=\mathrm{NS}$} & \multicolumn{2}{|c}{$\mathrm{E}=0.19, \mathrm{DAA}=0.01, \mathrm{E} X \mathrm{DAA}=0.02$} \\
\hline
\end{tabular}

\section{Discussion}

Chl ' $a$ ' fluorescence gives insights into the ability of a plant to tolerate environmental stresses and into the extent to which stresses have damaged the photosynthetic apparatus (Maxiwell \& Johnson, 2000) ${ }^{[12]}$. Therefore, it can be an excellent tool to study the stress induced changes in PSII which is believed to play a key role in the response of leaf photosynthesis to environmental stresses (Naumann et al. 2008) ${ }^{[15]}$. The $F_{v} / F_{m}$ value is the most frequently used parameter to indicate injury to the PSII complexes due to the stress factors including drought. Sayer et al. (2008) observed that chlorophyll fluorescence extinction measurement seems to be the most reliable test enabling the discrimination of wheat varieties according to their drought tolerance. As shown in Table 1, the chlorophyll fluorescence decreased under drought stress in leaves of both wheat varieties, however, the extent of reduction was more in WH 1105 than WH 1025 indicating higher injury to PS II. It was also observed that the chlorophyll fluorescence decreased from $7^{\text {th }}$ to $28^{\text {th }}$ DAA. The decrease in chlorophyll fluorescence could be the occurrence of chronic photo-inhibition due to photoinactivation of PS II centers, possibly attributable to D1 protein damage which usually limits photosynthetic activity (Zlatev, 2004) ${ }^{[25-26]}$. Similar results were obtained in drought susceptible variety of bean (Dobrudjanski ran) where a significant decrease in chlorophyll fluorescence was recorded, however, drought tolerant variety Prelom showed a slight tendency to decrease (Zlatev \& Yordanov, 2004) ${ }^{[25-26]}$. Khakwani et al. (2012) ${ }^{[10]}$ reported that there is a significant effect of water stress on chlorophyll fluorescence. Contrary to these Lobna et al. (2009) ${ }^{[8]}$ showed that $F_{v} / F_{m}$ was unaffected during the time-course of salt treatment. Wang et al. (2010) [23] also reported that combination of drought and heat stress resulted in a more drastic decline of $\mathrm{F}_{\mathrm{v}} / \mathrm{F}_{\mathrm{m}}$ than each stress alone. Similarly, Rai et al. (2011) ${ }^{[16]}$ reported a reduction in $\mathrm{F}_{\mathrm{v}} / \mathrm{F}_{\mathrm{m}}$ ratio in wheat at different days after leaf expansion under ambient ozone. The results are also at par with the findings of Flagella et al. (1995) ${ }^{[3]}$ who reported a decrease in photosynthetic efficiency $\left(\mathrm{F}_{\mathrm{v}} / \mathrm{F}_{\mathrm{m}}\right.$ ratio) in tolerant wheat cultivars grown under drought stress.

Canopy temperature is an indicator of crop water status. It needs to be recognized that diurnal temperature data includes a large number of measurements that are not indicative of water status. Canopy temperatures during the periods of darkness and cool cloudy days are not particularly sensitive to the water status of the crop. Results in Table 2 shows that canopy temperatures increased under drought stress at different stages of grain development in wheat leaves. The maximum canopy temperature of $31.98{ }^{\circ} \mathrm{C}$ was recorded at $28^{\text {th }}$ DAA in WH 1105. Canopy temperatures were comparatively lower in WH 1025 indicating that this variety was able to maintain better crop water status despite poor functioning of stomata.

Drought tolerance is a complex trait where several characteristics influence plant success during vegetation

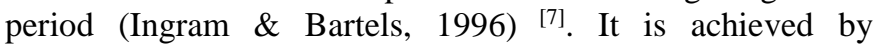
modulation of gene expression and accumulation of specific protective proteins and metabolites (Reddy et al. 2004; Zang $\&$ Komastu, 2007) ${ }^{[17,24]}$. Generally drought induces the metabolic changes related to protein turn over (alterations in 
protein synthesis, maintain the level of some proteins or protein degradation) (Bray, 1993) ${ }^{[1]}$. The present study reveals that the total soluble protein content decreased under drought stress in wheat leaves at different developmental stages of grain with more reduction observed in WH 1105 than WH 1025. Under irrigated conditions WH 1025 maintained higher amounts of soluble protein than WH 1105 (Table 3). The results of the present study are well supported by Gong et al. (2008) ${ }^{[4]}$ who reported that the content of total soluble protein was significantly decreased by drought stress. Simova-Stoilova et al. (2008) reported that total soluble protein levels in leaves does not clearly indicate senescence symptoms driven by severe drought at seedling stage. On the contrary, Muhammad et al. (2012) ${ }^{[14]}$ reported that salt stress caused a marked increase in total soluble proteins in wheat cultivars; however, the pattern of accumulation of soluble proteins was not consistent across the different salt regimes applied. Giuseppe et al. (2009) [5] identified 21 different proteins, including some of their isoforms and sub-units associated with drought stress exposure in wheat.

\section{Conclusions}

Chlorophyll fluorescence (Fv/Fm) was observed more in WH 1105 (15.73 per cent) as compared to WH 1025 (11.31 per cent). Canopy temperature of both wheat varieties increased under drought stress condition. More increase was observed in WH 1105 than WH 1025. However from $7^{\text {th }}$ to $28^{\text {th }}$ days after anthesis the canopy temperature gradually decreased in WH 1105 (7.68 to 4.17 per cent), as well as in WH 1025 (4.94 to 2.80 per cent).

Soluble protein content decreased under drought stress in both varieties, but more reduction was observed in WH 1105. The per cent decrease in soluble protein content was found to be more in WH 1105 than WH 1025 with respect to different grain developmental stages.

\section{Acknowledgements}

The authors acknowledge the help received from Department Crop Physiology, CCSHAU-Hisar for extension of field and laboratory facilities. Special thanks are due to Karanam Chinna Babu for proof reading and preparation of the manuscript.

\section{References}

1. Bray EA. Molecular responses to water deficit. Plant Physiology 1993;103:1035-1040.

2. Ezat-Ollah F, Mohsen F, Shokuh D. Comparison between effective selection criteria ofdrought tolerance in bread wheat landraces of Iran. Annals of Biological Research 2012;3(7):3381-3389.

3. Flagella Z, Pastore D, Campanile RG, Di Fonzo N. The quantum yield of photosynthesis electron transport evaluated by chlorophyll fluorescence as an indicator of drought tolerance in wheat. Journal of Agricultural Science Cambridge 1995;125:325-329.

4. Gong HJ, Chen KM, Zhao ZG, Chen GC, Zhou WJ. Effects of silicon on defense of wheat against oxidative stress under drought at different developmental stages. Biologia Plantarum 2008;52(3):592-596.

5. Giuseppe C, Chiara C, Patrizia F, Riccardo G, Roberto S, Aldo L. Analysis of drought responsive proteins in wheat (Triticum durum) by 2D-PAGE and MALDI-TOF mass spectrometry. Plant Science 2009;177:570-576.

6. Hojjat H, Mohammad TA, Ali A, Seyyed RS. Evaluation of some physiological traits associated with improved drought tolerance in Iranian wheat. Annals of Biological Research 2012;3(4):1719-1725.

7. Ingram J, Bartels D. The molecular basis of dehydration tolerance in plants. Annual Review of Plant Physiology and Plant Molecular Biology 1996;47:377-403.

8. Lobna Z, Gharbi F, Rezgui F, Rejeb S, Nahdi H, Rejeb MN. Application of chlorophyll fluorescence for the diagnosis of salt stress in tomato Solanum lycopersicum (variety Rio Grande)'. Scientia Horticulturea 2009;120:367-372.

9. Lowry OH, Rosenbrough NJ, Farr AL, Randall JL. Protein measurement with Folin-phenol reagent. Journal of Biological Chemistry 1951;193:265-275.

10. Khakwani AA, Dennett MD, Munir M, Baloch M. Wheat yield response to physiologicallimitations under water stress condition. The Journal of Animal and Plant Science 2012;22(3):773-780.

11. Kocheva K, Kartseva T, Landjeva S, Georgiev G. Parameters of cell membrane stability and levels of oxidative stress in leaves of wheat seedlings treated with PEG 6000. General and Applied Plant Physiology 2009;35(3-4):127-133.

12. Maxwell K, Johnson GN. Chlorophyll fluorescence a practical guide. Journal of Experimental Botany 2000;51:659-668.

13. Moussavi-Nik M, Rengel Z, Pearson JN, Hollamby G. Dynamics of nutrient remobilization from seed of wheat genotypes during imbibitions, germination and early seedling growth. Plant and Soil 1997;197:271-280.

14. Muhammad AA, Muhammmad A, Muhammad S. Growth stage-based modulation in antioxidant defense system and proline accumulation in two hexaploid wheat (Triticum aestivum L.) cultivars differing in salinity tolerance. Flora 2012;207:388-397.

15. Naumann JC, Young DR, Anderson JE. Leaf chlorophyll fluorescence, reflectance, and physiological response to freshwater and salt water flooding in the evergreen shrub. Myrica cerifera, Environmental and Experimental Botany 2008;63(1):402-409.

16. Rai R, Agarwal M, Agarwal SB. Effects of ambient $\mathrm{O}_{3}$ onwheat during reproductivedevelopment: Gas exchange, phtosynthestic pigments, chlorophyll fluorescence, and carbohydrates. Photosynthetica 2011;49(2):285-294.

17. Reddy AR, Chaitanya KV, Vivekanandan M. Droughtinduced responses of photosynthesis and antioxidant metabolism in higher plants. Journal of Plant Physiology 2004;161:1189-1202.

18. Sayaer R, Kemira H, Kameli A, Mosbahi M. Physiological tests as predictive appreciation for drought tolerance in durum wheat (Triticum aestivum Desf.). Agronomy Research 2008;6:79-90.

19. Shadana K, Noshin I, Nauima B, Muhammad A. Amelioration of drought stress in wheat by application of PGPR, compost and mineral fertilizer. Journal of Plant Nutrition 2017;40(9):1250-1260.

20. Simora-Stoilova L, Demirevska K, Petrova T, Tsenon N, Feller U. Antioxidant protection in wheat varieties under severe recoverable drought at seedling stage. Plant, Soil and Environment 2008;54(12):529-536.

21. Sudhakara RD, Raghavendra M, Parveen G, Shashi M, Renu M. Physiological responses associated with drought stress during grain filling period in Wheat (Triticum aestivum L.), The Pharma Innovation Journal 2020;9(11):106-110. 
22. Usha C, Bhumika P. Oxidative stress in five wheat varieties (Triticum aestivum L.) exposed to water stress and study of their antioxidant enzyme defence system, water stress responsive metabolites and $\mathrm{H}_{2} \mathrm{O}_{2}$ accumulation. Brazalian Journal of Plant Physiology 2012;24(2):117-130.

23. Wang GP, Zhang XY, Li F, Luo Y, Wang W. Over accumulation of glycine betaine enhancestolerance to drought and heat stress in wheat leaves in the protection of photosynthesis. Phytosynthetica 2010;48(1):117-126.

24. Zang X, Komastu S. A proteomic approach for identifying osmotic stress-related proteins in rice. Phytochemistry 2007;68:426-437.

25. Zlatev ZS. Drought induced changes in chlorophyll fluorescence of young wheat plants. Biotechnology and Biotechnological Equipment, 23/2009/Se XI Anniversary Scientific Conference Bulgaria 2004.

26. Zlatev ZS, Yordanov IT. Effects of soil drought on photosynthesis and chlorophyll fluorescence in bean plants. Bulgarian Journal of Plant Physiology 2004;30:318. 